\title{
Nutrient Management in Support of Environmental and Agricultural Sustainability
}

Andrew P. Whitmore ${ }^{1{ }^{1} *}$, Keith W. T. Goulding ${ }^{1}$, Margaret J. Glendining ${ }^{2}$, A. Gordon Dailey ${ }^{1}$, Kevin Coleman ${ }^{1}$ and David S. Powlson ${ }^{1}$

1 Soils and Grasslands Systems Science Department, Rothamsted Research, Harpenden, Hertfordshire, AL5 2JQ, UK; E-Mails: keith.goulding@rothamsted.ac.uk (K.W.T.G.); gordon.dailey@rothamsted.ac.uk (A.G.D.); kevin.coleman@rothamsted.ac.uk (K.C.); david.powlson@rothamsted.ac.uk (D.S.P.)

2 Department of Computational and Systems Biology, Rothamsted Research, Harpenden, Hertfordshire, AL5 2JQ, UK; E-Mail: margaret.glendining@rothamsted.ac.uk

* Author to whom correspondence should be addressed;

E-Mail: andy.whitmore@rothamsted.ac.uk; Tel.: +44-1582-763133; Fax: +44-1582-469036.

Received: 9 July 2012; in revised form: 12 September 2012 / Accepted: 24 September 2012 /

Published: 2 October 2012

Abstract: Given that we must farm land in order to eat, the total environmental burden imposed by farming a crop, such as winter wheat in the UK, appears to be close to the minimum given current production techniques. The value of the services other than food production, such as flood water buffering, pollination, carbon storage and so on, that land can provide is relatively large compared with the value in reducing environmental burdens from pesticide use, nutrient pollution and greenhouse gas emissions that might arise by farming less intensively. More land will need to be brought into cultivation in order to provide the same amount of food if the intensity of farming is reduced and the resultant loss of ecosystem services (ES) outweighs the reduction in other burdens. Nevertheless, losses of nutrients, especially nitrogen $(\mathrm{N})$, from agriculture are a serious concern and the current cost of the environmental footprint of agriculture is significant compared with the value of the food it produces. This article examines nutrient burdens and analyses the means by which the total environmental burden might be reduced relative to productivity. These include increasing the efficiency of farming, removing constraints to yield, and establishing multiple uses for land at the same time as farming. It concludes that agronomic measures which improve nutrient capture and which obtain more yield per unit area are 
valuable means to avoid degradation of environmental quality because both nutrient pollution and land consumption can be avoided.

Keywords: soil; modelling; nutrients; nutrient management; nitrogen use efficiency; crop production

\section{Introduction}

Glendining et al. [1] developed a framework for comparing the financial outputs and inputs of agriculture: that is a framework that includes both the orthodox economic evaluation but also the environmental costs of agriculture. Essentially they considered the ratio of the value of all outputs to the costs of all inputs. Such a ratio is known as the Total Factor Productivity (TFP, [2,3]). Glendining et al. [1] calculated TFP for farm production but also included multiple outputs (grain and straw for e.g. bedding or fuel) as well as the environmental costs as inputs without which TFP would be biased [3]. They showed that for arable crops at least, current farming practice that is optimal for profit is very nearly optimal for environmental quality. Farming in Western Europe is very intensive but Glendining et al.'s [1] conclusion was that reducing this intensity made little sense from an environmental point of view, if more land has to be brought into production in order to produce the same amount of food. Although reducing the intensity of farming did indeed appear to reduce nutrient and greenhouse gas emissions, the value of these gains was strongly outweighed by the cost associated with the loss of the ecosystem services (ES) from the new land brought under the plough. Such arguments support the concept of land sparing [4].

If the argument is taken as sound that land consumption is the primary environmental burden to be minimised, the question then becomes: can current nutrient use in farming practice be improved in the context of this primary constraint? This article takes a systems approach to agriculture with a particular focus on minimising nutrient losses while avoiding the need to farm a greater area of land. Taking data published by Glendining et al. [1] and analysing the profit and environmental costs more fully that are associated with producing a winter wheat crop as an example, we examine the scientific literature for ways in which farming might be improved to (i) deliver more profit without additional damage to the environment, (ii) deliver increased environmental quality without loss of yield, or (iii) increase both profit and environmental quality.

There has been some discussion in the literature surrounding the suitability of the TFP index, most notably concerning its static nature and the role of time by definition in the concept of sustainability. Glendining et al. [1] and Barnett et al. [3] discuss some of these issues which are beyond the scope of the current article.

\section{Results and Discussion}

In Figure 1, the environmental costs of farming wheat are broken down into those arising from the use of pesticides and other crop protection, $\mathrm{N}$ and $\mathrm{P}$ eutrophication, $\mathrm{N}_{2} \mathrm{O}$, other GHG emissions and loss of ecosystem service from land (bars) and displayed against the total cost of farming at 
increasingly intensive rates of production. The ecosystem service benefit of arable land is given as a negative cost (small pink bar). Also shown in Figure 1 is the response (line) conceived as profit plotted against the same intensity of production. This line displays the usual diminishing return to inputs. Yield is indicated on a secondary axis. Intensity of production is largely equivalent to the nitrogen applied in this example. Maximum profit is delivered at about the same point of the total input cost (abscissa) as the minimum environmental burden. Note, however, that the environmental cost is large at this minimum and far from trivial. Farming has a cost to the environment yet the fact that this environmental cost registers as larger than the farm profit is misleading, because environmental costs are not included in farm profit and loss accounts. If they were, the cost of food would change markedly.

Figure 1: Environmental costs and profits as a result of growing winter wheat, plotted against total costs (orthodox economic costs plus environmental costs). Coloured bars: breakdown of environmental costs (pesticide burden, $\mathrm{N}$ and $\mathrm{P}$ loss, $\mathrm{N}_{2} \mathrm{O}$ emission, other greenhouse gases (GHG) emissions, loss of ecosystem services (ES) of native land and gain for arable land). Costs are driven mainly by increases in nitrogen fertiliser, but other costs vary with production too. Solid line: farmer's profit as a result of growing winter wheat at the same costs of production. The yield equivalent of this profit (same solid line) is indicated with reference to the scale on the right hand axis.

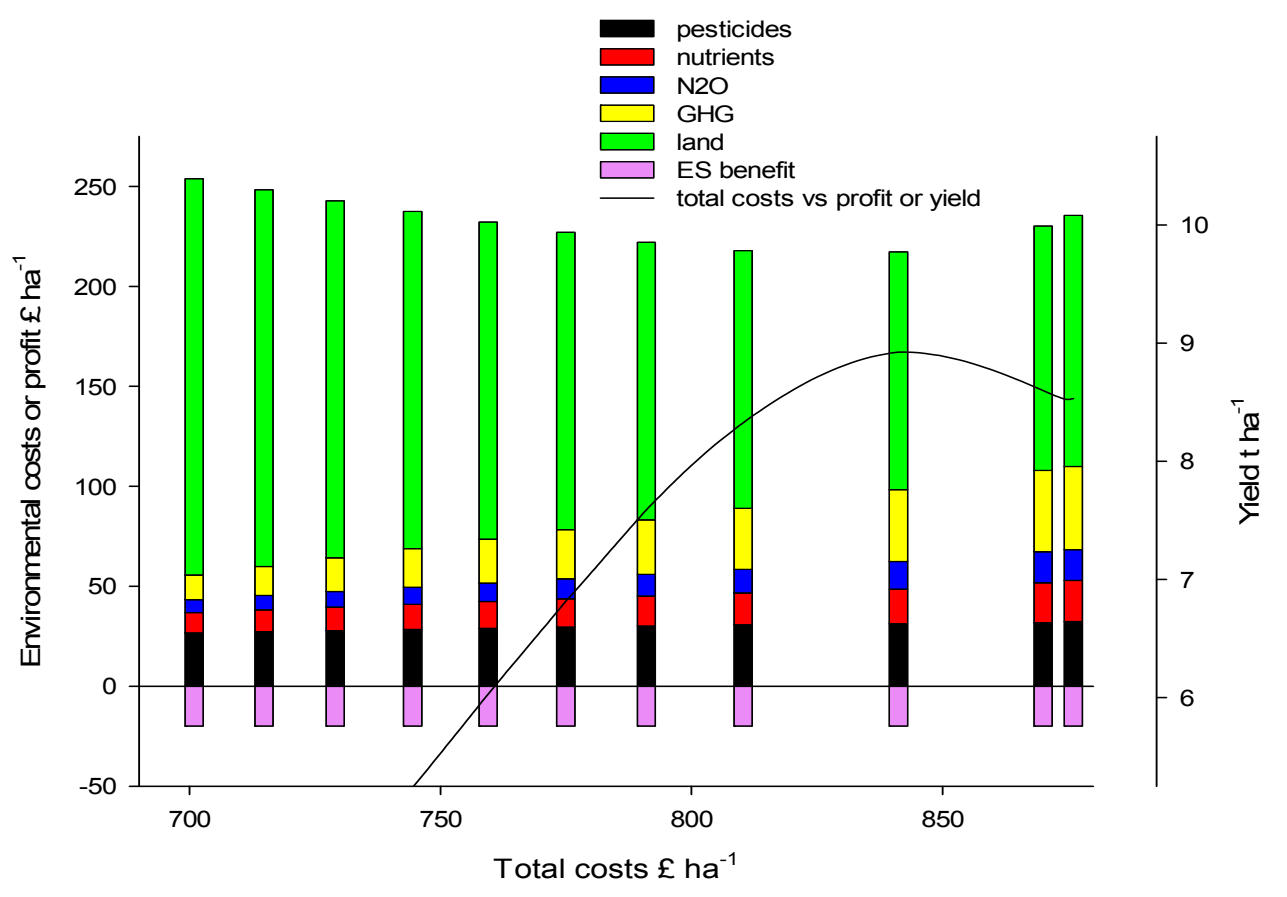

\subsection{Analysis of Nutrient Loss in Relation to Soil and Environmental Quality}

To illustrate Glendining et al.'s [1] claim that reducing inputs to agriculture substantially does not improve environmental quality, consider the effect of reducing inputs to winter wheat from those which produce maximum yield to those which produce a zero financial return. The environmental cost associated with bringing the extra land into production that is needed to make 
up the shortfall in productivity on a national basis is $£ 40$ (Figure 1, change in height of green bars and expressed on a per hectare basis). Compared with this, the saving in all other environmental costs for the same change is $£ 25$. Of this $£ 25$ just $£ 4$ comes from reducing leaching $\mathrm{N}$ and $\mathrm{P}$ and less than $£ 5$ comes from the reduction in $\mathrm{N}_{2} \mathrm{O}$ emissions (Figure 1). These prices were correct in 2006 (see methods).

If this is so, and if we accept that farming is necessary to feed ourselves, then what insights does this full environmental economic analysis provide that can help to improve soil and environmental quality and especially reduce nutrient pollution? Possible means to achieve improved environmental quality are listed in the first column of Table 1 as well as indicated on Figure 1. Table 1 includes drivers that state the pressure on farmers to improve environmental quality and indicate a potential means to achieve the change in some cases: A: The crop takes up and removes more nutrients from soil. B: Losses are reduced by whatever means. C: The efficiency of farming is improved. D: Constraints to crop growth are removed, which improves nutrient capture from soil. E: Dissemination and uptake of advice is improved to achieve optimal nutrient use and yield more widely. F: The value and extent of ES delivered by arable land is increased. This paper contains a summary of interventions that might achieve more efficient use of nitrogen and management of the crop as indicated in Figure 1. Fuller details can be found in the supplementary material online.

Table 1: Means to improve soil and environmental quality.

\begin{tabular}{|c|c|c|c|c|}
\hline & Means & $\begin{array}{c}\text { Effect on soil and/or } \\
\text { Environmental Quality }\end{array}$ & Driver & Possible means to achieve this \\
\hline $\mathbf{A}$ & $\begin{array}{l}\text { Increase nutrient } \\
\text { capture }\end{array}$ & Pollution is reduced & Economics & 1. Use of subsoil $\mathrm{N}$ \\
\hline B & $\begin{array}{l}\text { Reduce losses of } \mathrm{N} \text { to } \\
\text { the environment }\end{array}$ & Less pollution & Regulation & $\begin{array}{l}\text { 1. Use of nitrification inhibitors } \\
\text { 2. Splitting } \mathrm{N} \text { application to reduce } \\
\text { risk of loss }\end{array}$ \\
\hline $\mathrm{C}$ & $\begin{array}{l}\text { Decrease area of } \\
\text { farmed land directly }\end{array}$ & $\begin{array}{l}\text { Better provision of } \\
\text { Ecosystem Services other } \\
\text { than food and fibre } \\
\text { production }\end{array}$ & $\begin{array}{l}\text { Pressure from other } \\
\text { users of land }\end{array}$ & $\begin{array}{l}\text { 1. Maximising efficiency of } \\
\text { production }\end{array}$ \\
\hline D & $\begin{array}{l}\text { Remove constraints } \\
\text { on yield }\end{array}$ & $\begin{array}{l}\text { Less land needed, } \\
\text { less } \mathrm{N} \text { needed }\end{array}$ & $\begin{array}{l}\text { Economics, yield } \\
\text { increases if constraints } \\
\text { are removed }\end{array}$ & $\begin{array}{l}\text { 1. Use of canopy management } \\
\text { techniques } \\
\text { 2. Breeding } \\
\text { 3. Management of root environment }\end{array}$ \\
\hline $\mathbf{E}$ & $\begin{array}{l}\text { Improve effectiveness } \\
\text { of extension }\end{array}$ & $\begin{array}{l}\text { Less waste, production can } \\
\text { be optimised for both yield } \\
\text { and environmental quality. }\end{array}$ & $\begin{array}{l}\text { Economics/ } \\
\text { Regulation }\end{array}$ & $\begin{array}{l}\text { 1. Improved guidance on use of } \\
\text { nutrients } \\
\text { 2. Improved understanding of } \mathrm{N} \\
\text { cycles } \\
\text { 3. Adoption of precision management }\end{array}$ \\
\hline $\mathbf{F}$ & $\begin{array}{l}\text { Increase ES or } \\
\text { functionality of } \\
\text { farmland }\end{array}$ & $\begin{array}{l}\text { More services of better } \\
\text { quality delivered per unit } \\
\text { area of land }\end{array}$ & $\begin{array}{l}\text { Pressure from other } \\
\text { users of land }\end{array}$ & $\begin{array}{l}\text { 1. Increase organic matter levels } \\
\text { 2. Adopt some form of mixed } \\
\text { cropping }\end{array}$ \\
\hline
\end{tabular}




\subsection{Specific Means to Improve Soil and Environmental Quality}

If unfarmed land supplies more ES than farmed, it makes sense to use the farmed area as efficiently as possible in order to avoid bringing land into production. So a loss of environmental quality can be avoided by increasing nutrient capture or by increasing yield, if this avoids consumption of land. Below we consider the ways in which environmental quality might be improved in this context.

\subsubsection{Increase Nutrient Capture (A)}

Bradley et al. [5] report the distribution of soil carbon in England and Wales. They give data from which the average density of carbon in the subsoil $(30-70 \mathrm{~cm})$ can be deduced as $0.5 \% \mathrm{C}$ by weight. A typical $\mathrm{C}: \mathrm{N}$ ratio for soil is 10 or less and so this implies very crudely that the average density of $\mathrm{N}$ in the subsoil is $0.05 \%$, or half the threshold of $(0.1 \% \mathrm{~N})$ that Sylvester-Bradley et al. [6] suggest might contribute significant amounts of $\mathrm{N}$ through mineralisation to the soil nitrogen supply to crops. Without a reported distribution or other measure of the variation it is difficult to state the prevalence of soils containing more than $0.1 \% \mathrm{~N}$ in the UK, but it is unlikely to be greater than $25 \%$ of all soils. On the other hand a soil containing $0.05 \% \mathrm{~N}$ in the soil volume from 30 to $100 \mathrm{~cm}$ may supply up to a third of the $\mathrm{N}$ contained in the topsoil and so about 20 or $30 \mathrm{~kg} \mathrm{~N} \mathrm{ha}^{-1} \mathrm{yr}^{-1}$, which would probably be leached if not captured by a crop. Such $\mathrm{N}$ is not currently accounted for in advisory systems. Where such $\mathrm{N}$ is available to crops, nitrogen application could be reduced by the equivalent amount.

\subsubsection{Reduce Losses (B)}

Recent research in New Zealand and Australia has shown that nitrification inhibitors (NIs) can be extremely effective at reducing $\mathrm{N}_{2} \mathrm{O}$ emissions from intensively grazed pasture [7]. If the nitrification of ammonium $\mathrm{N}$ is prevented, less leaching results and less $\mathrm{N}_{2} \mathrm{O}$ is emitted during both nitrification and the subsequent denitrification of the resultant nitrate $\left(\mathrm{NO}_{3}^{-}\right)$. NIs applied to urine patches have been found to reduce $\mathrm{N}_{2} \mathrm{O}$ emissions by $61-91 \%$, to reduce $\mathrm{NO}_{3}^{-}$leaching by $30-79 \%$ and increase annual pasture yield by $0-36 \%$ [8-13]. Rates of application were of the order of $10 \mathrm{~kg} \mathrm{DCD}$ (Dicyandiamide) $\mathrm{ha}^{-1}$ at a cost of about $£ 26 \mathrm{ha}^{-1}$. Research is currently underway in the UK and the Republic of Ireland to attempt to verify these findings for conditions in the British Isles.

Ammonia emissions can be reduced by the use of urease inhibitors [13] and as a consequence indirect emissions of $\mathrm{N}_{2} \mathrm{O}$ can be reduced. There is some evidence to suggest that urea is more suited for use on soils prone to waterlogging (because it is primarily lost in dry conditions), whilst ammonium nitrate is more suited to less wet soils (because it is primarily lost under wet conditions) [14]. Although NIs were effective at field capacity in this study, they were ineffective under waterlogged conditions.

Delays and manipulation of delays in mineralization of $\mathrm{N}$ from crop residues by means of added material having a wide $\mathrm{C}: \mathrm{N}$ have been reported [15] as has the effect of clay in soil on temporarily stabilizing N [16]. Better understanding of the mechanisms underlying these phenomena might lead to interventions to retain nitrogen in soil in organic forms until such time as a growing crop could take it up. 
There is evidence that $\mathrm{N}_{2} \mathrm{O}$ production increases at a non-linear rate when soil $\mathrm{NO}_{3}{ }^{-}$content exceeds crop demand. This has been reported under maize [17,18] and spring barley [19]. Under these conditions, and when conditions are also conducive to denitrification, splitting fertilizer $\mathrm{N}$ applications could reduce $\mathrm{N}_{2} \mathrm{O}$ losses. Data presented by Zebarth et al. [19] suggest that lack of crop $\mathrm{N}$ uptake accounts for the relative increase in the proportion of mineral $\mathrm{N}$ that is emitted as $\mathrm{N}_{2} \mathrm{O}$ at high rates of $\mathrm{N}$ application. Dalal et al. [20] state that $\mathrm{NO}_{3}{ }^{-}$usually inhibits full denitrification of $\mathrm{N}_{2} \mathrm{O}$ to $\mathrm{N}_{2}$, increasing the $\mathrm{N}_{2} \mathrm{O}: \mathrm{N}_{2}$ ratio. This lends weight to the view that splitting applications should reduce losses and that correct $\mathrm{N}$ fertiliser guidance is imperative.

\subsubsection{Decrease Area of Farmed Land Directly (C)}

If efficiencies can be found throughout the system, less land need be used, which reduces the environmental footprint of farming as a whole. Alternatively, farmed land might be made more productive. Bulson et al. [21] found a $29 \%$ increase in yields from barley and beans by intercropping at $150 \%$ total density compared with sole crops. Not only does this increase diversity (see F below) but less land is needed to produce the same amount of food, thus potentially increasing the supply of valuable ES on land no longer in arable production [4].

\subsubsection{Remove Constraints (D)}

Removing constraints on productivity is likely to increase yield profitability; it may well also affect the shape of the response curve, shifting the optimum in the direction of either less or more inputs. Careful use of growth regulators and fungicides with growth regulation properties, and maintaining the correct amount of $\mathrm{N}$ in soil for sufficient but not excessive growth, have been found to increase oilseed rape yields by $0.36 \mathrm{t} \mathrm{ha}^{-1}$ [22]. Lynch [23] asserts that crops tend to develop roots in the surface soil for nutrient acquisition (particularly P) and in the subsoil for water. Ho et al. [24] suggest that plants which increase the density of their roots in the topsoil are able to acquire P more effectively than those which do not. They argue further that genotypes with roots that proliferate deep in the soil are better able to withstand drought stress but also found dimorphic varieties that are able to adapt to either nutrient or water stress as appropriate. Waines and Ehdaie [25] conclude that the root systems of modern wheat cultivars are small, having perhaps two thirds of the root mass of the landraces from which they derive. Whitmore et al. [26] argue that the physical impediment to root growth is a more significant stress than the lack of accessibility of water. There thus seems scope for breeding to improve nutrient acquisition and to reduce other constraints to maximum yield and nutrient uptake such as water stress.

If water or root condition is limiting yield [27], removing the constraint(s) and allowing the crop to yield to its full potential should improve nutrient use and benefit environmental quality by reducing losses and emissions. A further benefit of removing constraints to yield is that the farmer gains profit and so there is a strong economic pull from this direction, provided the action needed to remove the constraint is not excessively costly compared with the gain in yield. Because the costs of environmental pollution generally fall over the wider environment, measures to reduce nutrient loss have often been delivered through support (e.g. the EU single farm payment). 


\subsubsection{Improve Effectiveness of Extension (E)}

The benefit of improved extension can also be seen to act by moving the system towards the optimum production level (Figure 1). Removing constraints to crop growth increases profit and increases the ratio of profit to environmental cost. If the economic and environmental optima are not precisely aligned [1], advice to minimise deterioration of environmental quality will need to be focused on the environmental rather than economic optimum. This can save the cost of fertilizer and as well as environmental pollution. Dailey et al. [28] suggest that improved weather forecasts will make small (6 or $7 \mathrm{~kg} \mathrm{~N} \mathrm{ha}^{-1}$ ) but systematic improvements to $\mathrm{N}$ offtake and yield where $\mathrm{N}$ applications are constrained by regulation such as in nitrate vulnerable zones. Recent research in NW Europe on the effectiveness of extension has tended to focus on meeting air and water quality standards (e.g. [29]) but the advice itself is often based on achieving the economic optimum [30]. Goulding et al. [31] report that nitrogen use efficiency can be $60-90 \%$ on experimental plots but sometimes as little as 20 $50 \%$ on cereal farms; this gap might be bridged by improved extension or outreach from researchers.

If $\mathrm{N}$ is uniformly applied at a rate necessary to obtain the maximum or optimum yield, given the existence of spatial variability [32] reduction of $\mathrm{N}$ use should reduce losses, but yields cannot be expected to improve detectably. There may be factors other than $\mathrm{N}$ supply that limit yield. If so, the simplistic approach of applying more $\mathrm{N}$ where growth is poor may be ineffective in increasing yield and risk environmental losses of $\mathrm{N}$. Thus where nutrients cannot be captured by a crop, it makes environmental sense to apply less. It does seem likely, however, that $\mathrm{N}_{2} \mathrm{O}$ emission and $\mathrm{NO}_{3}^{-}$leaching can be reduced by applying $\mathrm{N}$ in a spatially variable way, since several studies have found no loss of yield with a reduction in total $\mathrm{N}$ applied (e.g. [33-35]). Savings in these terms have rarely been identified in the literature but could be substantial in global or national terms if most emissions derive from the under-use of applied $\mathrm{N}$ by crops (perhaps $1-2 \mathrm{~kg} \mathrm{~N}_{2} \mathrm{O}-\mathrm{N} \mathrm{ha}^{-1}$ or $50 \mathrm{~kg} \mathrm{NO}_{3}^{-}-\mathrm{N} \mathrm{ha}^{-1} \mathrm{y}^{-1}$.)

\subsubsection{Increase ES and Functionality of Farmed Land (F)}

Even arable land provides ecosystem services. If a way could be found to increase the services or value of the services provided by arable land then the net environmental cost of farming would be less. For example, Whitmore and Schröder [36] showed that intercropping could reduce nutrient use and nitrate leaching by $20-40 \mathrm{~kg} \mathrm{~N} \mathrm{ha}^{-1}$, without loss of yield or profit. Some measures have multiple effects. For example, increasing organic matter levels can increase soil fertility and, provided increased $\mathrm{N}$ supply from soil is taken into account, applications of fertiliser $\mathrm{N}$ can be reduced [37]. In addition, Watts et al. [38] found that increasing organic carbon in soil by $0.1 \%$ could reduce the specific plough draught by $5 \mathrm{kPa}$, which represents a fuel saving of more than $5 \%$. Arable land that helped control flooding could make a large and valuable contribution to both the full economy of the UK [39] and to environmental quality downstream. Clearly not all land can perform all services simultaneously, but UK arable production managed as a whole might, even if not all in the same place. Multi-functional land-use at the landscape scale is therefore a means to improve environmental quality as a whole while continuing to farm the food we need to feed ourselves. However, it is important to consider the results of measures to ensure that increasing an ES such as carbon sequestration does not inadvertently lead to unexpected increases in a pollutant such as $\mathrm{N}_{2} \mathrm{O}$ emissions [40]. 


\section{Methodology}

Glendining et al. [1] published methodology and spreadsheets for calculating the costs of producing and managing crops. Orthodox economic costs of inputs and operations were derived from agricultural almanacs such as Nix [41] and ABC [42]. Environmental costs were taken from national surveys of environmental impacts and Life Cycle Assessment [43-47] and attributed to sectors on a land-area basis; they include the cost of manufacture and transport of inputs such as fertilizer to the farm. Costs and burdens after agricultural products have left the farm gate are excluded. Prices were correct at the time (2006) this study was carried out. Agricultural commodity prices have risen and fallen sharply in the intervening period, emphasising the caution that must be applied when attributing and comparing costs to such diverse quantities as the additional health care as a result of using pesticides, the loss of value of amenity water as a result of eutrophication, the potential damage to the economy following emissions of greenhouse gases (GHG), the value of wheat grain and so on.

We consider nutrient losses in particular here. Glendining et al. [1] included nitrous oxide $\left(\mathrm{N}_{2} \mathrm{O}\right)$ emissions as part of the full GHG burden of agriculture but here we have separated out the component of the GHG burden that can be attributed to $\mathrm{N}_{2} \mathrm{O}$ emission from land when growing wheat in order to examine the fate of nutrients especially (Figure 1, blue bars). Any $\mathrm{N}_{2} \mathrm{O}$ emitted as a result of off-farm activity thus remains in the GHG data presented below (Figure 1, yellow bars), but emissions from soil under agriculture are displayed explicitly. Nutrient burdens refer to nitrate and phosphorus (P) losses by all means to surface water; ammonia is neglected in this data for a winter wheat crop. A large part of the environmental burden associated with $\mathrm{P}$ or $\mathrm{N}$ occurs from their joint impact on water quality. It is very difficult therefore to disentangle these effects and attribute them separately.

A major burden considered by Glendining et al. [1] was the cost of bringing land that bears woodland or native vegetation into cropping. Woodland and land in its natural state provides far more extensive and valuable ES than cropped land and this loss contributes strongly to any financial balance sheet that includes the valuation of environmental factors. Natural land supports a wider diversity of organisms, it maintains an extensive network of pores in soil that can store or transmit water, and natural vegetation, especially forest, is good at removing pollutants from the atmosphere. Agricultural grassland is considerably more valuable than arable land in this context but less valuable than native vegetation. Values of ES were taken from [48]; after discounting food and fibre production these were: arable land, $£ 20$ (US\$38 ha ${ }^{-1}$ in [48] exchange rate at the time the research was carried out) woodland $£ 119$ (US\$227 $\mathrm{ha}^{-1}$ ) with the caveat that these numbers are as subject to change as any other in the economic calculations, and that services will become more valuable than we now assume if the land able to provide them becomes scarce [49]. The source of additional land is assumed to be woodland, because grassland is already in agricultural use. If grassland were substituted instead, the conclusions would change little because the value of the ecosystem services provided by grassland was estimated at $£ 86\left(\$ 165 \mathrm{ha}^{-1}\right)$.

\section{Conclusions}

A degree of consumption of environmental services must be accepted if we are to feed ourselves; naturally this impacts on soil and environmental quality. Agronomic measures to save between 5 and 
$40 \mathrm{~kg} \mathrm{~N} \mathrm{ha}^{-1}$ have been identified as representative of valuable savings in fertilizers. Where this comes from, e.g. additional mineralization, fertilizer should be reduced, otherwise the $\mathrm{N}$ saved becomes a loss and therefore a cost to environmental quality. On the other hand, if the crop can respond to an extra $40 \mathrm{~kg} \mathrm{ha}^{-1}$, then the extra yield might be up to $1 \mathrm{tha}^{-1}$. UK winter wheat crops yield an average of $8 \mathrm{t} \mathrm{ha}^{-1}$ currently from just over $2 \mathrm{M}$ ha. An average increase to the bottom half of the distribution of $1 \mathrm{t} \mathrm{ha}^{-1}$ is equivalent to $0.1 \mathrm{M}$ ha of land from which ES might potentially be increased. Such a change would need to be made permanently, however, since native land is easy to consume but difficult to restore. The separate measures to improve soil or environmental quality proposed here are not mutually exclusive and indeed can be synergistic; for the most part a decrease in the environmental footprint at levels of production close to the maximum can be coupled with an increase in productivity and profit.

Although subject to caveats, TFP [50] methodology has wider environmental, as well as economic, uses.

\section{Acknowledgments}

Rothamsted Research is an institute of the UK Biology and Biotechnological Sciences Research Council. This work was partly supported by GB Department of the Environment, Food and Rural Affairs (Defra, IS0216, IF0175), the BBSRC Institute Strategic Programme grants on Delivering Sustainable Systems, Soil Sustainable Function (SoilCIP) and Bioenergy and Climate Change.

\section{Conflict of Interest}

The authors declare no conflicts of interest.

\section{References}

1. Glendining, M.J.; Dailey, A.G.; van Evert, F.K.; Williams, A.G.; Goulding, K.W.T.; Whitmore, A.P. Is it possible to increase the sustainability of arable and ruminant agriculture by reducing inputs? Agr. Syst. 2009, 99, 117-125.

2. Ehui, S.K.; Spenser, D.S.C. A General Approach for Evaluating the Economic Viability and Sustainability of Tropical Cropping Systems. In Issues in Agricultural Development; IAAE Occasional Paper No. 6; Bellamy, M., Greenshields, B., Eds.; CABI Publishing: Oxford, UK, 1992; pp. 110-119.

3. Barnett, V.; Landau, S.; Welham, S.J. Measuring Sustainability. Environ. Ecol. Stat. 1994, 1, $21-36$.

4. Green, R.E.; Cornell, S.J.; Scharlemann, J.P.W.; Balmford, A. Farming and the fate of wild nature. Science 2005, 307, 550-555.

5. Bradley, R.I.; Milne, R; Bell, J.; Lilly, A.; Jordan, C.; Higgins, A. A soil carbon and land use database for the United Kingdom. Soil Use Manage. 2005, 21, 363-369.

6. Sylvester-Bradley, R.; Stokes, D.T.; Scott, R.K. Dynamics of nitrogen capture without fertilizer: The baseline for fertilizing winter wheat in the UK. J. Agr. Sci. 2001, 136, 15-33. 
7. de Klein, C.A.M.; Eckard, R.J. Targeted technologies for nitrous oxide abatement from animal agriculture. Aust. J. Exp. Agr. 2008, 48, 14-20.

8. Di, H.J.; Cameron, K.C. The use of a nitrification inhibitor, dicyandiamide (DCD), to decrease nitrate leaching and nitrous oxide emissions in a simulated grazed and irrigated grassland. Soil Use Manage. 2002, 18, 395-403.

9. Di, H.J.; Cameron, K.C. Mitigation of nitrous oxide emissions in spray-irrigated grazed grassland by treating the soil with dicyandiamide, a nitrification inhibitor. Soil Use Manage. 2003, 19, 284-290.

10. Di, H.J.; Cameron, K.C. Reducing environmental impacts of agriculture by using a fine particle suspension nitrification inhibitor to decrease nitrate leaching from grazed pastures. Agr. Ecosyst. Environ. 2005, 109, 202-212.

11. Di, H.J.; Cameron, K.C. Sources of nitrous oxide from N-15-labelled animal urine and urea fertiliser with and without a nitrification inhibitor, dicyandiamide (DCD). Aust. J. Soil Res. 2008, $46,76-82$.

12. Di, H.J.; Cameron, K.C.; Sherlock, R.R. Comparison of the effectiveness of a nitrification inhibitor, dicyandiamide, in reducing nitrous oxide emissions in four different soils under different climatic and management conditions. Soil Use Manage. 2007, 23, 1-9.

13. Dampney, P.; Richards, G.; Bhogal, A. Nitrogen Fertilising Materials; Report for Defra Project NT2601; Defra: London, UK, 2003.

14. Pathak, H.; Nedwell, D.B. Nitrous oxide emission from soil with different fertilizers, water levels and nitrification inhibitors. Water Air Soil Poll. 2001, 129, 217-228.

15. Vinten, A.J.A.; Whitmore, A.P.; Bloem, J.; Howard, R.; Wright, F. Factors affecting N immobilisation/mineralisation kinetics for cellulose, glucose and straw amended sandy soils. Biol. Fert. Soils 2003, 36, 190-199.

16. Whitmore, A.P.; Groot, J.J.R. The decomposition of sugar beet residues: Mineralization versus immobilization in contrasting soil types. Plant Soil 1997, 192, 237-247.

17. Chantigny, M.H.; Prevost, D.; Angers, D.A.; Simard, R.R.; Chalifour, F.P. Nitrous oxide production in soils cropped to corn with varying N fertilization. Can. J. Soil Sci. 1998, 78, 589-596.

18. McSwiney, C.P.; Robertson, G.P. Nonlinear response of $\mathrm{N}_{2} \mathrm{O}$ flux to incremental fertilizer addition in a continuous maize (Zea mays L.) cropping system. Glob. Change Biol. 2005, 11, $1712-1719$.

19. Zebarth, B.J.; Rochette, P.; Burton, D.L. $\mathrm{N}_{2} \mathrm{O}$ emissions from spring barley production as influenced by fertilizer nitrogen rate. Can. J. Soil Sci. 2008, 88, 197-205.

20. Dalal, R.C.; Wang, W.J.; Robertson, G.P.; Parton, W.J. Nitrous oxide emission from Australian agricultural lands and mitigation options: A review. Aust. J. Soil Res. 2003, 41, 165-195.

21. Bulson, B.A.J.; Snaydon, R.W.; Stopes; C.E. Effects of plant density on intercropped wheat and field beans in an organic farming system. J. Agr. Sci. 1997, 128, 59-71.

22. Berry, P.M.; Spink, J.H. "Canopy Management” and Late Nitrogen Applications to Improve Yield of Oilseed Rape; HGCA Report No 447; HGCA: Warwickshire, UK, 2009.

23. Lynch, S.P. Roots of the second green revolution Aust. J. Bot. 2007, 55, 493-512. 
24. Ho, M.D.; Rosas, J.C.; Brown, K.M.; Lynch, J.P. Root architectural tradeoffs for water and phosphorus acquisition. Funct. Plant Biol. 2005, 32, 737-748.

25. Waines, J.G.; Ehdaie, B. Domestication and crop physiology: Roots of green revolution wheat. Ann. Bot. 2007, 100, 991-998.

26. Whitmore, A.P.; Whalley, W.R.; Bird, N.R.A.; Watts, C.W.; Gregory, A.S. Estimating soil strength in the rooting zone of wheat. Plant Soil 2012, 339, 363-375.

27. Whitmore, A.P.; Whalley, W.R. Physical effects of soil drying on roots and crop growth. J. Exp. Bot. 2009, 60, 2845-2857.

28. Dailey, A.G.; Smith, J.U.; Whitmore, A.P. How far might medium-term weather forecasts improve nitrogen fertiliser advice and benefit arable farming in the UK? Agr. Ecosys. Environ. 2006, 117, 22-28.

29. Neeteson, J.J. Nitrogen and phosphorus management on Dutch dairy farms: Legislation and strategies employed to meet the regulations. Biol. Fert. Soils 2000, 30, 566-572.

30. Defra. Fertilizer Manual (RB209), 8th edition; TSO: Norwich, UK, 2012; p. 249.

31. Goulding, K.W.T.; Jarvis, S.C.; Whitmore, A.P. Optimising nutrient management for farm systems. Philos. T. Roy. Soc. 2008, 363, 667-680.

32. Whitmore, A.P.; Van Noordwijk, M. Bridging the Gap between Environmentally Acceptable and Agronomically Desirable Nutrient Supply. In Ecology and Integrated Farming Systems: Proceedings of the 13th Long Ashton International Symposium, 1993; Glen, D.M., Greaves, M.P., Anderson, H.M., Eds.; John Wiley and Sons: Chichester, UK, 1995; pp. 271-288.

33. Lark, R.M.; Wheeler, H.C. Experimental and Analytical Methods for Studying Within-Field Variation of Crop Responses to Inputs. In Proceedings of the 4th European Conference on Precision Agriculture. Stafford, J., Werner, A., Eds.; Wageningen Academic Publishers: Wageningen, The Netherlands. 2003; pp. 341-346.

34. Desbourdes, C.; Blondlot, A.; Douche, H. Variable Nitrogen Application with Satellite View. In Proceedings of the 9th International Conference on Precision Agriculture, Denver, Colorado, USA, 20-23 July 2008.

35. Robertson, M.J.; Lyle, G.; Bowden, J.W. Within-field variability of wheat yield and economic implications for spatially variable nutrient management. Field Crop. Res. 2008, 105, 211-220.

36. Whitmore, A.P.; Schröder, J.J. Intercropping reduces nitrate leaching from under field crops without loss of yield: A modelling study. Eur. J. Agron. 2007, 27, 81-88.

37. Whitmore, A.P.; Schröder, J.J. Modelling the change in soil organic $\mathrm{C}$ and $\mathrm{N}$ in response to applications of slurry manure. Plant Soil 1996, 184, 185-194.

38. Watts, C.W.; Clark, L.J.; Poulton, P.R.; Powlson, D.S.; Whitmore, A.P. The role of clay, organic carbon and cropping on plough draught measured on the Broadbalk Wheat Experiment at Rothamsted. Soil Use Manage. 2006, 22, 334-341.

39. Rouquette, J.R.; Posthumus, H.; Gowing, D.J.G.; Tucker, G.; Dawson, Q.L.; Hess, T.M.; Morris, J. Valuing nature-conservation interests on agricultural floodplains J. Appl. Ecol., 2009, 46, 289-296.

40. Powlson, D.S.; Bhogal, A.; Chambers, B.J.; Macdonald, A.J.; Coleman, K.; Goulding, K.W.T.; Whitmore, A.P. The potential to increase soil carbon stocks through reduced tillage or organic additions-An England and Wales case study. Agr. Ecosys. Environ. 2012, 146, 23-33. 
41. Nix, J. Farm Management Pocketbook, 35th Edition; Wye College: London, UK, 2005.

42. ABC. The Agricultural Budgeting and Costing Book No. 60; Agro Business Consultants Ltd.: Melton Mowbray, UK, 2005.

43. Atkinson, G.; Baldock, D.; Bowyer, C.; Newcombe, J.; Ozdemiroglu, E.; Pearce, D.; Provins, A. Framework for Environmental Accounts for Agriculture; Final Report; Economics for the Environment Consultancy: London, UK, 2004; p. 105.

44. Pretty, J.N.; Brett, C.; Gee, D.; Hine, R.E.; Mason, C.F.; Morison, J.I.L.; Raven, H.; Rayment, D.; van der Bijl, G. An assessment of the total external costs of UK agriculture. Agr. Sys. 2000, 65, 113-136.

45. Pretty, J.N.; Mason, C.F.; Nedwell, D.B.; Hine, R.E.; Leaf, S.; Dils, R. Environmental costs of freshwater eutrophication in England and Wales. Environ. Sci. Technol. 2003, 37, 201-208.

46. Hartridge, O.; Pearce, D. Is UK Agriculture Sustainable? Environmentally Adjusted Economic Accounts for UK Agriculture; CSERGE, University College: London, UK, 2001.

47. Williams, A.G.; Audsley, E.; Sandars, D.L. Environmental burdens of producing bread wheat, oilseed rape and potatoes in England and Wales using simulation and system modeling. Int. J. Life Cycle Ass. 2010, 15, 855-868.

48. Costanza, R.; D’Arge, R.; de Groot, R.; Farber, S.; Grasso, M.; Hannon, B.; Limbuirg, K.; Naeem, A.; O'Neill, R.V.; Paruelo, J.; et al. The value of the world's ecosystem services and natural capital. Nature 1997, 387, 253-260.

49. Farber, S.C.; Costanza, R.; Wilson, M.A. Economic and ecological concepts for valuing ecosystem services. Ecol. Econ. 2002, 41, 375-392.

50. Lynam, J.K.; Herdt, R.W. Sense and sustainability: Sustainability as an objective in international agricultural research. Agr. Econ. 1989 3, 381-398.

\section{Supplementary Material}

A review of related literature based on [1].

\section{Reference}

1. Whitmore, A.P.; Dailey, A.G.; Glendining, M.J.; Coleman, K.; Powlson, D.S.; Goulding, K.W.T. A Critical Review of Recent Policy-Relevant Research in Nitrogen Cycling; Final report for project IF0175; Defra: London, UK, 2010; p. 68.

(C) 2012 by the authors; licensee MDPI, Basel, Switzerland. This article is an open access article distributed under the terms and conditions of the Creative Commons Attribution license (http://creativecommons.org/licenses/by/3.0/). 